\title{
Cycling and early pregnant endometrium as a site of regulated expression of the vitamin $D$ system
}

\author{
P Viganò, D Lattuada, S Mangioni, L Ermellino', M Vignali², E Caporizzo ${ }^{3}$, \\ P Panina-Bordignon ${ }^{3}$, M Besozzi ${ }^{1}$ and A M Di Blasio' ${ }^{1}$ \\ Department of Obstetrics, Gynecology and Neonatology, Fondazione Policlinico-Mangiagalli-Regina Elena Hospital, University of Milano, Milano, Italy \\ ${ }^{1}$ Pathology Laboratory and Molecular Biology Laboratory, Istituto Auxologico Italiano, Via Zucchi, 18-Cusano Milanino, Milano, Italy \\ ${ }^{2}$ Dept of Obstetrics and Gynecology, Clinica Macedonio Melloni, University of Milano, Milano, Italy \\ ${ }^{3}$ BioXell S.p.A, Milano, Italy
}

(Requests for offprints should be addressed to A M Di Blasio; Email: a.diblasio@auxologico.it)

\begin{abstract}
In addition to its calciotropic function, the secosteroid 1,25-dihydroxyvitamin $D_{3}\left(1,25(O H)_{2} D_{3}\right)$, has potent anti-proliferative/immunomodulatory effects on various tissues. Consistently, the enzyme that catalyzes the synthesis of $1,25(\mathrm{OH})_{2} \mathrm{D}_{3}, 1 \alpha$-hydroxylase (1 $\alpha$-OHase) and the vitamin $\mathrm{D}$ receptor have a widespread tissue distribution. Among site-specific functions, the hormone has been suggested to be involved in uterine physiology. However, molecular analysis of the vitamin D system in normal endometrium throughout the menstrual cycle as well as its regulation in the context of endometrial physiological and pathological events have received very limited attention. Thus, we have studied expression, localization and regulation of $1 \alpha-\mathrm{OH}$ ase in human cycling and early pregnant endometrium. The capacity for $1 \alpha$-hydroxylation and the presence of vitamin $D$ receptor in endometrial cells have also been evaluated. The functional significance of these findings has been tested by evaluating gene expression of the catabolic enzyme, vitamin D 24-hydroxylase, and of the adhesion protein, osteopontin. Finally, to verify any potential dysfunction of the vitamin D system in endometriosis, a reproductive disease characterized by immune-mediated anomalies, we have analyzed expression of $1 \alpha-\mathrm{OH}$ ase in both eutopic and ectopic endometrium of affected patients. Results obtained showed that the active form of the $1 \alpha-\mathrm{OH}$ ase gene was expressed in human endometrial stromal cells independent of the cycle phase but with a significant increase in early pregnant decidua. A similar profile was observed for the protein, which was abundantly expressed in the cytoplasm of both endometrial stroma and epithelial glands. Both cycling and early pregnant endometrial cells also expressed the vitamin D receptor. In the same cells, $1 \alpha$-OHase mRNA levels were significantly stimulated by the pro-inflammatory cytokine interleukin (IL)-1 $\beta$ (50 and $500 \mathrm{pg} / \mathrm{ml}$ ) while addition of the active form of the hormone could modulate both CYP24 and osteopontin gene expression. The $1 \alpha$-OHase gene was also expressed in ectopic endometrium and its levels were increased in proliferative phase cultures derived from patients with endometriosis. Human cycling endometrium may be included among the extrarenal sites able to synthesize vitamin D. The IL-1 $1 \beta$-mediated induction of $1 \alpha$-OHase gene and the hormonal modulation of osteopontin support a role for the hormone in the immunological mechanisms underlying uterine function. Abnormalities of this system are present in endometriosis.
\end{abstract}

Journal of Molecular Endocrinology (2006) 36, 415-424

\section{Introduction}

Vitamin $\mathrm{D}$ is a major regulator of mineral ion homeostasis by facilitating calcium and phosphate uptake in the gut and by modulating bone cell development and action (Kumar 1980, Jones et al. 1998). However, the most potent metabolite of vitamin $\mathrm{D}$, the secosteroid 1,25-dihydroxyvitamin $\mathrm{D}\left(1,25(\mathrm{OH})_{2} \mathrm{D}_{3}\right)$, has also been demonstrated to affect a wide range of functions not immediately linked to calcium homeostasis, suggesting a much broader physiological impact of the hormone in the body than originally envisioned (Zehnder et al. 2001). Specifically, $1,25(\mathrm{OH})_{2} \mathrm{D}_{3}$ has been shown to exert anti-proliferative and immunosuppressive effects on several cell types (Peehl et al.1994, Lemire et al. 1995, Muller \& Bendtzen 1996, Long \& Santos 1999). The importance of $1,25(\mathrm{OH})_{2} \mathrm{D}_{3}$ as a pleiotropic modulator of tissue functions is strengthened by the presence of key components of vitamin D metabolism at different sites. The cognate nuclear receptor for $1,25(\mathrm{OH})_{2} \mathrm{D}_{3}$ (VDR) is ubiquitous in proliferating cells (Hewison et al. 2000) and the mitochondrial cytocrome $\mathrm{P} 450$ enzyme 25-hydroxyvitamin $\mathrm{D}_{3}$-1 $\alpha$-hydroxylase (1 $\alpha$-OHase), which catalyzes the synthesis of $1,25(\mathrm{OH})_{2} \mathrm{D}_{3}$ from its precursor 25-hydroxyvitamin $\mathrm{D}_{3}$, is expressed in the kidney and in several extrarenal tissues (Zehnder et al. 2001, 2002b). The widespread co-expression of VDR and $1 \alpha$-OHase emphasizes a 
putative role for $1,25(\mathrm{OH})_{2} \mathrm{D}_{3}$ as an autocrine/paracrine agent with diverse physiological functions (Hewison et al. 2000).

In the late 1980s and early 1990s, particular attention was directed towards the potential significance of the vitamin $\mathrm{D}$ endocrine system in human reproductive processes. Increased circulating levels of $1,25(\mathrm{OH})_{2} \mathrm{D}_{3}$ were observed during estroprogestins treatment as well as during human gestation (Kumar 1980, Hartwell et al. 1990, Salle et al. 2000). Moreover, uterine and placental cells were shown to synthesize $1,25(\mathrm{OH})_{2} \mathrm{D}_{3}$ (Acker et al. 1982, Delvin et al. 1985, Kachkache et al. 1993) and a single report demonstrated elevated serum levels of the hormone in a specific pathological condition of the reproductive system, endometriosis (Hartwell et al. 1990), which is characterized by immune system anomalies (Vignali et al. 2002).

In the last years, interest in this specific topic has been greatly increased for two reasons: (i) the development of mice deficient in VDR or $1 \alpha$-OHase has revealed that these animals show impaired ovarian folliculogenesis and uterine hypoplasia (Yoshizawa et al. 1997, Kinuta et al. 2000, Panda et al. 2001) and (ii) vitamin D seems to influence the reproductive system not only at the ovarian level but also at the endometrial level. Indeed, some of the genes recently identified to be uniquely regulated at the site of embryo implantation, for instance calbindinD9k in the mouse and the homeobox (Hox) A10 gene in humans, are vitamin D-dependent proteins (Rots et al. 1998, Nie et al. 2000, Salamonsen et al. 2002, Du et al. 2005).

To further investigate the significance of local $1,25(\mathrm{OH})_{2} \mathrm{D}_{3}$ production in the human uterus, in the present study we have analyzed endometrial expression of $1 \alpha$-OHase at both the mRNA and protein levels during the menstrual cycle and in early pregnancy. Local regulation of the enzyme by factors physiologically present at the fetal-maternal interface has also been addressed. Furthermore, we have investigated whether endometrial $1 \alpha$-OHase expression could effectively result in the synthesis of the hormone from its precursor $25(\mathrm{OH}) \mathrm{D}_{3}$, verified the presence of the hormone receptor in endometrium and analyzed the functional effects of these results by evaluating the induction of specific target genes. Finally, to confirm the potential role of the vitamin D system in endometriosis, we have evaluated $1 \alpha$-OHase expression in both eutopic and ectopic endometrium of affected patients.

\section{Materials and methods}

\section{Reagents}

Progesterone and $25(\mathrm{OH}) \mathrm{D}_{3}$ were purchased from Sigma (Milano, Italy). Human recombinant interleukin (IL)- $1 \beta$ and tumor necrosis factor- $\alpha$ (TNF- $\alpha$ ) were obtained from Amersham Biosciences (Amersham, Cologno Monzese, Italy). Culture medium consisted of Ham's F-10 (Sigma, Italy) supplemented with $2 \mathrm{mM}$ L-glutamine (Sigma, Italy), antibiotics, fungizone and 10\% heat-inactivated FCS (Sigma, Italy). Collagenase A was purchased from Roche (Milano, Italy) and hyaluronidase from Sigma (Mountain View, CA, USA). All reagents for real-time quantitative PCR were from Applied Biosystems (Foster City, CA, USA). Primers for $1 \alpha$-OHase and hypoxanthine phosphoribosyltransferase-1 (HPRT-1) used for qualitative PCR analysis were from Sigma. A conventional RIA kit for the quantitative measurement of $1,25(\mathrm{OH})_{2} \mathrm{D}_{3}$ was obtained from DiaSorin (Stillwater, MN, USA). Monoclonal antibody to vitamin D receptor was from Alexis Biochemicals (Lausen, Switzerland), antibody to $\beta$-actin was from Sigma, antiserum to $1 \alpha$-OHase was from The Binding Site (Birmingham, UK) and anti-CD45-FITC/CD14-PE was from Becton Dickinson.

\section{Sample collection}

Human samples were obtained from women who attended the endoscopic surgical service of the II Department of Obstetrics and Gynecology of the University of Milan to undergo gynecological laparoscopy for unexplained infertility, pelvic pain or benign ovarian pathology. Women with previous autoimmune, neoplastic, hepatic or thyroid disorders were excluded from the study. All subjects were younger than 40, had regular menstrual cycles and none had received hormones for at least 3 months.

Samples of uterine endometrium were obtained from 77 women. At laparoscopic visualization, $27 \mathrm{had}$ evidence of endometriosis that was staged, according to the Revised American Fertility Society Classification (1997) (American Society for Reproductive Medicine 1997), as minimal (stage I) in 4 cases, mild (stage II) in 5 cases, moderate (stage III) in 11 cases and severe (stage IV) in 7 cases. In the 50 patients in whom endometriosis was not diagnosed, laparoscopic examination demonstrated normal pelvic organs in 6 cases, pelvic adhesions in 7 cases, benign ovarian pathology in 22 cases and benign uterine pathology in 15 cases. Among patients with endometriosis 14 were in the proliferative and 13 in the secretory phase of the cycle, while among controls 22 were in the proliferative and 28 in the secretory phase. Dating was based on the last menstrual period and on histological examination of the samples.

Endometriotic samples from peritoneal lesions and endometriotic cysts were excised from nine patients with severe endometriosis at operation and immediately frozen at $-80^{\circ} \mathrm{C}$.

Decidual tissues were obtained from 38 healthy women undergoing elective termination of normal pregnancies between 8 and 13 weeks of gestation. The 
operative method used was cervical dilatation followed by vacuum extraction of the products of conception. After a careful aspiration of all the trophoblastic material, a biopsy curette was used to obtain decidual tissue.

Patients were informed in detail that serum or tissue samples would be used for research purposes and they gave a written consent. Approval for this study was granted by the local Human Institutional Investigation Committee.

\section{Cell culture}

Establishment of stromal cell monolayers from normal endometrial tissue has been described in detail in previous studies (Viganò et al. 1993). Diffuse and strong cytoplasmatic immunostaining for vimentin was demonstrated in nearly all $(90 \%)$ cultured endometrial stromal cells. Cytofluorimetric analysis showed that leukocyte contamination (CD45-positive cells) of our cultures was less than $2 \%$. Briefly, tissue was minced and digested in $10 \mathrm{ml}$ Ham's F-10 containing $0 \cdot 2 \%$ collagenase. Single stromal cells were separated from epithelium by differential sedimentation at unity gravity and selective adhesion to tissue culture dishes. Decidual tissue was minced thoroughly between two scalpels and digested for $1 \mathrm{~h}$ in HAM'S F-10 with $0 \cdot 1 \%$ collagenase and $0 \cdot 2 \%$ hyaluronidase. Decidual cells were then separated from dead cells and red cells by Ficoll-Hypaque density gradient. The cells at the interface were plated and left at $37^{\circ} \mathrm{C}$ overnight, then washed several times to remove non-adherent cells and debris. Endometrial or decidual cells were cultured to subconfluence in Ham's F-10 with 10\% FCS and antibiotics in a humidified atmosphere of $95 \%$ air and $5 \% \mathrm{CO}_{2}$ at $37^{\circ} \mathrm{C}$. Subconfluence was reached after a minimum of 8 days during which culture medium was changed every other day. To evaluate the effects of different compounds on endometrial $1 \alpha$-OHase mRNA expression, endometrial stromal cells were cultured with $0 \cdot 1 \%$ bovine serum albumin when stimulated for $24 \mathrm{~h}$ with and without IL-1 $\beta$ or TNF- $\alpha$ and with charcoalstripped calf serum when stimulated for up to 9 days with and without progesterone. To evaluate the effects of $1,25(\mathrm{OH})_{2} \mathrm{D}_{3}$ on endometrial vitamin D-24-hydroylase gene (CYP24) and osteopontin mRNA expression, cells were cultured with $0 \cdot 1 \%$ bovine serum albumin with and without different concentrations of the hormone for four hours.

\section{Immunohistochemistry}

Immunohistochemical analysis of $1 \alpha$-OHase expression was performed using a previously described method (Zehnder et al. 2002b). Briefly, tissues were formalinfixed, paraffin-embedded, cut into $4-\mu \mathrm{m}$ sections and placed on pre-treated slides. Sections were dewaxed and rehydrated through graded alcohol using standard procedures. They were processed in $0.01 \mathrm{M}$ sodium citrate buffer $(\mathrm{pH} 6.0)$ in a microwave for $15 \mathrm{~min}$ at the maximum power for antigen retrieval. Slides were then incubated with $1 \%$ hydrogen peroxide in Tris-buffered saline, $\mathrm{pH} 7 \cdot 6$ to block endogenous peroxidase activity, and then washed in Tris. The slides were then incubated with $1 \alpha$-OHase antiserum $(1: 150)$ in $10 \%$ normal swine serum overnight at $4{ }^{\circ} \mathrm{C}$. After rinsing with Trisbuffered saline for $15 \mathrm{~min}$, donkey anti-sheep IgG peroxidase conjugated (1:200) was added to sections for $45 \mathrm{~min}$. Staining was developed using 3,3'diaminobenzidine $(2.5 \mathrm{mg} / \mathrm{ml})$ followed by counterstaining with Mayer's hematoxylin. Negative control sections included the omission of primary antibody, the use of primary antibody preadsorbed with a 100 -fold excess of immunizing peptide or the analysis of the liver as a negative tissue (Zehnder et al. 2001).

\section{Extraction of mRNA, qualitative RT-PCR analysis for $1 \alpha-O H a s e$ and sequence analysis}

Total RNA was extracted from cells and tissues using Trizol (Invitrogen Life Technology, Carlsbad, CA, USA). One microgram total RNA was transcribed into cDNA using $1 \mathrm{mM}$ of each $\mathrm{dNTP}, 0.75 \mu \mathrm{g}$ random hexamer primers, 25 units RNase inhibitor, and 200 units reverse transcriptase (RT) (Promega Corporation, Madison, WI, USA) in a total volume of $25 \mu \mathrm{l}$. cDNA was amplified with $500 \mathrm{nM} 1 \alpha$-OHase-specific primers (upstream: 5' ATG ACG CAG ACG CTG AAG 3'; downstream: 5' GTG GGA GAC TAC GTT GTT CAG 3') using RedTaq DNA polymerase (Sigma) according to the following protocol: $94^{\circ} \mathrm{C}$ for $5 \mathrm{~min}(1$ cycle), $94^{\circ} \mathrm{C}$ for $30 \mathrm{~s}, 59^{\circ} \mathrm{C}$ for $30 \mathrm{~s}, 72^{\circ} \mathrm{C}$ for $30 \mathrm{~s}(38$ cycles), $72^{\circ} \mathrm{C}$ for $5 \mathrm{~min}$ (1 cycle). The primers were designed to generate a fragment of $492 \mathrm{bp}$ that spans two introns. In each experiment, a negative control was prepared using all reagents and substituting $1 \mu \mathrm{l}$ water for the reverse transcriptase. Integrity of RNA and absence of genomic contamination was assessed by amplification of HPRT-1 gene as previously described (Viganò et al. 2002). The specificity of the products generated by the indicated primers was verified by sequence analysis.

\section{Evaluation of gene expression by real-time RT-quantitative PCR (RT-qPCR) analysis}

One microgram total RNA was reverse transcribed for $2 \mathrm{~h}$ at $37^{\circ} \mathrm{C}$ using the high-capacity cDNA archive kit. The ABI Prism 7900 sequence detection system (Applied Biosystems) was used for real-time RT-qPCR analysis using HPRT-1 as an endogenous control. Real-time PCR was performed using specific primers and probes for 1 $\alpha$-OHase, osteopontin and CYP24 target genes 
(Assays-on-Demand Gene Expression Products, Applied Biosystems). Validation experiments were performed using the 1:2 diluted templates. Reaction conditions included $10 \mu \mathrm{l} 2 \times$ TaqMan Universal PGR Master Mix, $1 \mu \mathrm{l}$ primers and probes mixture, $50 \mathrm{ng}$ template cDNA and nuclease-free water on a 96-well reaction plate. The total reaction volume was $20 \mu \mathrm{l}$. The cycling conditions were as follows: $2 \mathrm{~min}$ at $50{ }^{\circ} \mathrm{C}, 10 \mathrm{~min}$ at $95^{\circ} \mathrm{C}$, and 40 cycles of $15 \mathrm{~s}$ at $95^{\circ} \mathrm{C}$ followed by $1 \mathrm{~min}$ at $60{ }^{\circ} \mathrm{C}$. The data were analyzed using the comparative $\mathrm{Ct}$ method, where $\mathrm{Ct}$ is the cycle number at which fluorescence first exceeds the threshold. The $\Delta$ cycle threshold $(\Delta \mathrm{Ct})$ values from each sample were obtained by subtracting the values for the reference gene from the sample Ct. For each experimental sample the $2^{-\Delta \mathrm{Ct}}$ has been calculated and data have been graphically indicated as relative expression.

\section{Western blot for VDR and 1 $\alpha-O H a s e$}

Samples of endometrial stromal and decidual cell cultures were treated with a lysis buffer containing $150 \mathrm{mM} \mathrm{NaCl}, 10 \mathrm{mM}$ Tris-HCl, $1 \mathrm{mM}$ EDTA, $1 \%$ Triton X-100, 10\% glycerol, $1 \mathrm{mM}$ PMSF, $10 \mu \mathrm{g} / \mathrm{ml}$ leupeptin and $10 \mu \mathrm{g} / \mathrm{ml}$ aprotinin. Lysates were subsequently centrifuged at $13000 \boldsymbol{g}$ for $30 \mathrm{~min}$ and the supernatant was collected for protein analysis. Sample protein concentration was determined using a commercial protein assay kit (BCA Protein Assay Kit, Pierce Biotechnology, Rockford, IL, USA). Proteins resolved by SDS-PAGE were transferred to Hybond EGL nitrocellulose membranes (Amersham, Italy). For VDR detection, after brief washing in TBST $(25 \mathrm{mM}$ Tris-HCl (pH 7·5), $50 \mathrm{mM} \mathrm{NaCl}, 0 \cdot 1 \%$ Tween 20), the membrane was blocked with $5 \%$ skim milk plus $5 \%$ BSA/TBST overnight at $4{ }^{\circ} \mathrm{C}$. All subsequent steps were performed at room temperature. The membrane was incubated for $3 \mathrm{~h}$ with $11 \mu \mathrm{g}$ anti-VDR antibody diluted

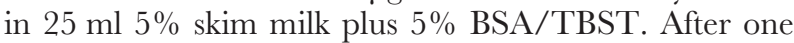
hour washing with TBST, membranes were incubated for $1 \mathrm{~h}$ with peroxidase-conjugated anti-rat IgG (Sigma). For $1 \alpha$-OHase detection, the membrane was blocked with 5\% skim milk plus 5\% BSA in TBST for $2 \mathrm{~h}$ at room temperature. The membrane was incubated overnight with anti-1 $\alpha$-OHase antibody diluted 1:500 in $5 \%$ skim milk plus 5\% BSA/TBST. After $1 \mathrm{~h}$ washing with TBST, membranes were incubated for $1 \mathrm{~h}$ with peroxidase-conjugated anti-sheep IgG (Sigma). For protein load control, anti- $\beta$-actin mouse monoclonal antibodies were used. Anti-mouse $\operatorname{IgG}$ secondary antibody was used at 1:5000 dilution. Bound antibodies were visualized by chemiluminescence. Control experiments were included where primary antibody was omitted or primary antibody was preabsorbed with a 100-fold excess of immunizing peptide.

\section{Measurement of $1,25(\mathrm{OH})_{2} \mathrm{D}_{3}$ production}

Endometrial cells were seeded $\left(5 \times 10^{5} \mathrm{cell} / \mathrm{s} / \mathrm{well} / \mathrm{ml}\right)$ in a 6 -well plate. After washing with serum-free medium, cells were incubated with different concentrations of $25(\mathrm{OH}) \mathrm{D}_{3}$ solubilized in absolute ethanol $(0 \cdot 1 \%$ final concentration) in $1 \%$ FCS culture medium for $24 \mathrm{~h}$. The conditioned medium and cell monolayers were harvested. The quantitative detection of $1,25(\mathrm{OH})_{2} \mathrm{D}_{3}$ levels was performed using a commercially available RIA kit with an intra-assay coefficient of variation of $6 \cdot 8-11 \cdot 3 \%$, an interassay coefficient of variation of $11 \cdot 2-14 \cdot 6 \%$ and a sensitivity of $<2 \mathrm{pg} / \mathrm{ml}$. The concentration of $1,25(\mathrm{OH})_{2} \mathrm{D}_{3}$ levels was expressed as $\mathrm{pg} / \mathrm{ml}$.

\section{Statistical analysis}

Differences between groups were compared, as appropriate, by unpaired Student's $t$-test, analysis of variance (ANOVA) and Fisher protected least significant difference-test as post-test. Probability $<0.05$ was considered to be statistically significant.

\section{Results}

\section{Expression of $1 \alpha-O H a s e$ and vitamin $D$ receptor in normal endometrium}

Normal endometrial stromal cells obtained from samples in different phases of the menstrual cycle and early pregnant decidual cells were first evaluated for $1 \alpha$-OHase mRNA expression by qualitative RT-PCR. During cell isolation and culture, a great effort was directed towards the complete elimination of immune cells as potential contaminants. Only cell populations 98\% free of CD45and CD14-positive cells as evaluated by phenotypic analysis were included in the study. PCR products were consistently detected in all samples analyzed (Fig. 1A). Estimated and actual size of the PCR products was $492 \mathrm{bp}$. The identity of the amplified products with the primer-defined $1 \alpha$-OHase DNA sequence was confirmed by sequence analysis (data not shown). Quantification of $1 \alpha$-OHase mRNA levels in early pregnant decidual cells and in endometrial cells in different phases of the cycle was performed by real-time RT-qPGR analysis. Results of the experiments performed in normal endometrial stromal cells derived from $n=28$ different tissues $(n=13$ and $n=15$ in the proliferative and secretory phases respectively) and decidual cells obtained from $n=25$ different samples indicated that levels of $1 \alpha$-OHase mRNA were similar in endometrial stromal cells independent of the phase of the cycle but were significantly increased in decidual cells $(P<0 \cdot 05)$ (Fig. 1B). Western blot analysis showed that the observed differences in $1 \alpha$-OHase mRNA levels were maintained at the protein level. A single western blot species $(56 \mathrm{kDa})$ that corresponded to

www.endocrinology-journals.org 

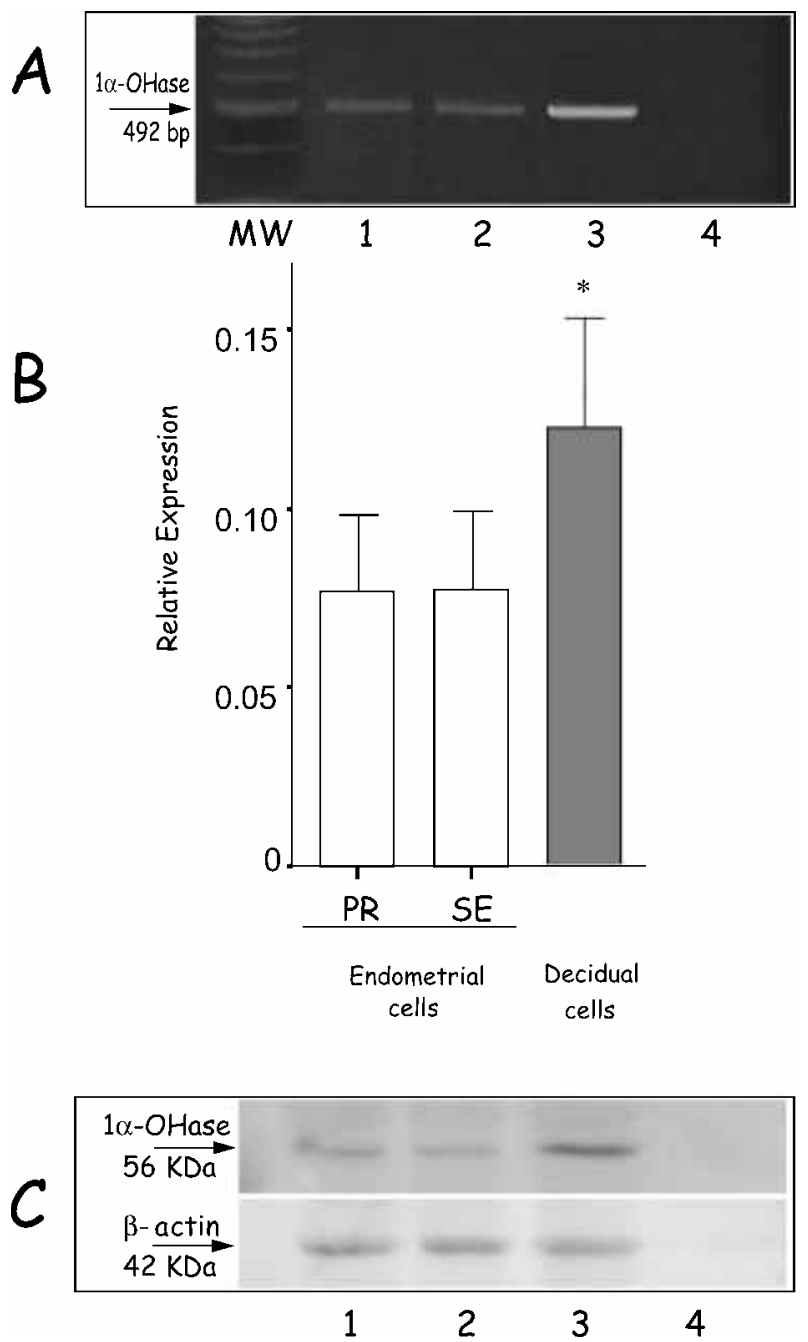

Figure 1 Expression of $1 \alpha$-OHase in normal cycling endometrial stromal cells and early pregnant decidual cells.

(A) Qualitative RT-PCR of representative cases of proliferative phase endometrial stromal cells (lane 1), secretory phase endometrial stromal cells (lane 2) and early pregnant decidual cells (lane 3). Size marker is shown in the first left lane of the gel (MW). Lane 4 shows the negative control performed by substituting $1 \mu \mathrm{l}$ water for the RNA. (B) Real time-qPCR analysis of $1 \alpha-\mathrm{OH}$ ase mRNA in cultured cells derived from $n=13$ proliferative phase endometrial samples (PR), $n=15$ secretory phase endometrial samples (SE) and $n=25$ decidual samples. Data are presented as mean \pm S.E.M. $1 \alpha-\mathrm{OHase}$ relative expression. ${ }^{*} P<0.05$ versus decidual cells.

(C) Western blot profile of total homogenate of endometrial and decidual cells. Three representative cases of proliferative phase endometrial stromal cells (lane 1), secretory phase endometrial stromal cells (lane 2 ) and early pregnant decidual cells (lane 3 ) are shown. Lane 4 represents a negative control in which primary antibody was preabsorbed with a 100 -fold excess of immunizing peptide. Detection of $\beta$-actin was used for protein load control. the reported renal $1 \alpha$-OHase (Fig. $1 \mathrm{C}$ ) was detected in both proliferative $(n=3)$ and secretory $(n=3)$ phase endometrial stromal cells and in first trimester decidual cells $(n=4)$. Densitometric analysis of western blots showed an increase of about $40 \%$ in $1 \alpha$-OHase expression in decidua versus normal cycling endometria of both phases.

To determine the cellular localization of $1 \alpha$-OHase, its expression was also evaluated by immunohistochemistry. Comparable immunostaining for $1 \alpha$-OHase was present in the endometrium of both proliferative and secretory phases (Fig. 2C,D). The protein was abundantly expressed in the cytoplasm of both stromal and epithelial layers with a diffuse distribution. As relative high levels of $1 \alpha$-OHase protein have previously been shown in first trimester decidua (Zehnder et al. 2002b) this tissue was used as the positive control (Fig. 2A,B). Immunopositive cells were diffusely distributed throughout the decidua and had no special relationship with the blood vessels. Staining was absent in the negative controls (Fig. 2E,F).

To evaluate whether the cycling endometrium could also be a target of $1,25(\mathrm{OH})_{2} \mathrm{D}_{3}$ action, the presence of nuclear receptor VDR protein was investigated in proliferative $(n=3)$ and secretory $(n=3)$ phase endometrial stromal cells by western blot analysis. Decidual cells $(n=4)$ have previously been shown to express the vitamin $\mathrm{D}$ receptor and were used as a positive control (Zehnder et al. 2002b). Rat antibody to human VDR reacted with both endometrial and decidual samples resulting in a band of $54 \mathrm{kDa}$ (Fig. 3).

\section{Regulation of $1 \alpha-\mathrm{OHase}$ gene expression in normal endometrial stromal cells}

We also investigated transcriptional regulation of $1 \alpha$-OHase expression in endometrial stromal cells by IL-1 $\beta(n=6)$, TNF- $\alpha(n=6)$ or progesterone $(n=6)$ using real time RT-qPCR. IL-1 $\beta$, at concentrations of 50 and $500 \mathrm{pg} / \mathrm{ml}$, significantly increased $1 \alpha$-OHase expression by $44 \%$ and $130 \%$ respectively, while TNF- $\alpha$ at concentrations of $0 \cdot 1 \mathrm{ng} / \mathrm{ml}$ and $1 \mathrm{ng} / \mathrm{ml}$ could not elicit a significant increase (Fig. 4). Incubation for up to 9 days with progesterone had no effect on endometrial $1 \alpha$-OHase mRNA levels (data not shown). Similar experiments could not be performed in epithelial endometrial cells given the difficulty in sub-culturing this particular cell population (Viganò et al. 1993). Thus, no conclusions can be inferred for the regulation of $1 \alpha$-OHase expression in glandular cells.

\section{Production of $1,25(\mathrm{OH})_{2} \mathrm{D}_{3}$ and effect of the hormone on specific target genes in endometrial and decidual cells}

Measurement of $1,25(\mathrm{OH})_{2} \mathrm{D}_{3}$ levels in the supernatant of endometrial stromal cells treated with $25(\mathrm{OH}) \mathrm{D}_{3}$ 

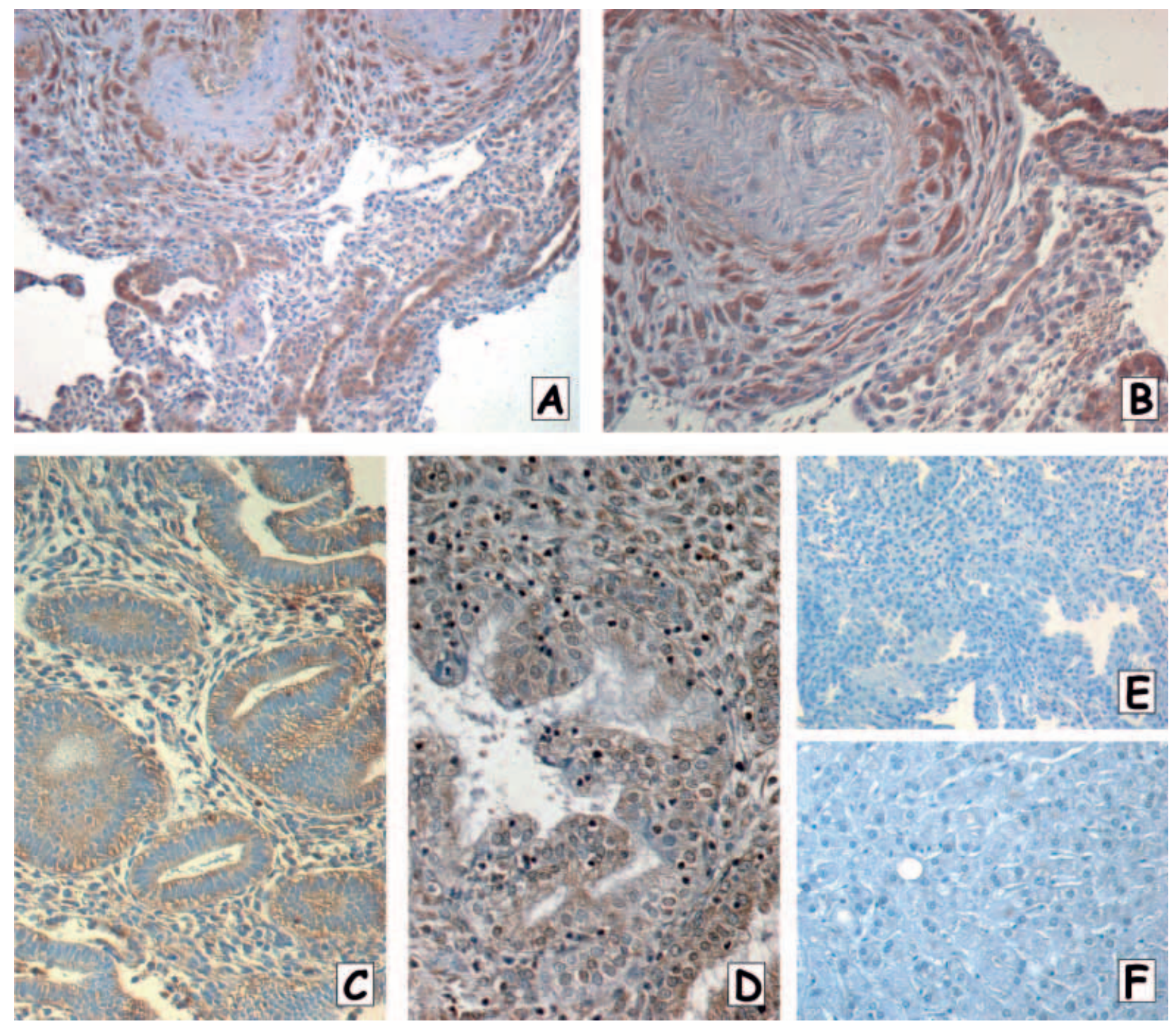

Figure 2 Cellular localization of $1 \alpha-\mathrm{OHase}$ in human cycling endometrium and early pregnant decidua as evaluated by immunohistochemistry. The presence of immunoreactive $1 \alpha-\mathrm{OH}$ ase is indicated by the brown staining in the cytoplasm of both epithelial and stromal cells of endometrial biopsies collected during the proliferative (C) and the secretory (D) phase of the menstrual cycle. Similarly, early pregnant decidua show $1 \alpha-$ OHase immunostaining (A, low magnification; B, higher magnification) The negative controls for specificity of $1 \alpha$-OHase expression were performed by preabsorbing the antiserum with 100 -fold excess of immunizing peptide $(E)$ or testing a negative tissue such as the liver $(F)$. (Original magnification: $\times 100$ for $A$ and $E$ and $\times 200$ for B,C,D and F.)

resulted in a constitutive and dose-dependent production of the hormone, thus indicating that endometrium represents a site of local conversion from the precursor to the active form (Fig. 5A). Levels of produced $1,25(\mathrm{OH})_{2} \mathrm{D}_{3}$ were similar to those detected in other recognized extrarenal sites of production (Fritsche et al. 2003).

The functional consequences of $1,25(\mathrm{OH})_{2} \mathrm{D}_{3}$ production and the presence of VDR were tested by evaluating the expression level of two target genes, CrP24 and osteopontin. CYP24 is one of the most potent $1,25(\mathrm{OH})_{2} \mathrm{D}_{3}$-responding genes and its protein product is responsible for the hydroxylation reaction that deactivates the biologically active vitamin $\mathrm{D}$ sterol. Osteopontin is an adhesion molecule with roles in implantation and decidualization (Johnson et al. 2003) and is regulated by vitamin $\mathrm{D}$ in different tissues (Christakos et al. 2003). Levels of CYP24 mRNA were negligible in unstimulated endometrial cells and were detectable but still very low in unstimulated decidual 


\section{$\underset{54 \mathrm{KDa}}{\stackrel{\mathrm{VDR}}{\longrightarrow}}$}

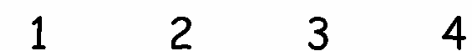

Figure 3 Expression of VDR in endometrial stromal cells and early pregnant decidual cells as evaluated by Western blot. Three representative cases of proliferative phase endometrial stromal cells (lane 1), secretory phase endometrial stromal cells (lane 2) and early pregnant decidual cells (lane 3 ) are shown. Lane 4 represents a negative control in which primary antibody was preabsorbed with a 100-fold excess of immunizing peptide.

cells. A significant and strong increase was observed in both types of culture after addition of $1,25(\mathrm{OH})_{2} \mathrm{D}_{3}$ for $4 \mathrm{~h}$ (Fig. 5B). Similar to that reported for other fibroblast-like cells (Tashiro et al. 2004), in endometrial cells transcription levels went up to about 2000-fold for a $1,25(\mathrm{OH})_{2} \mathrm{D}_{3}$ concentration of $1000 \mathrm{nM}$; in decidual cells this increase was still very strong. Cells were also tested for osteopontin expression, which in the basal condition, as previously reported by von Wolff et al. (2004), was significantly increased in decidual cells when compared with endometrial stroma. Addition of $1,25(\mathrm{OH})_{2} \mathrm{D}_{3}$ for $4 \mathrm{~h}$ at a concentration of $1000 \mathrm{nM}$ significantly stimulated osteopontin expression levels by about $60-70 \%$ in both types of culture (Fig. 5C).
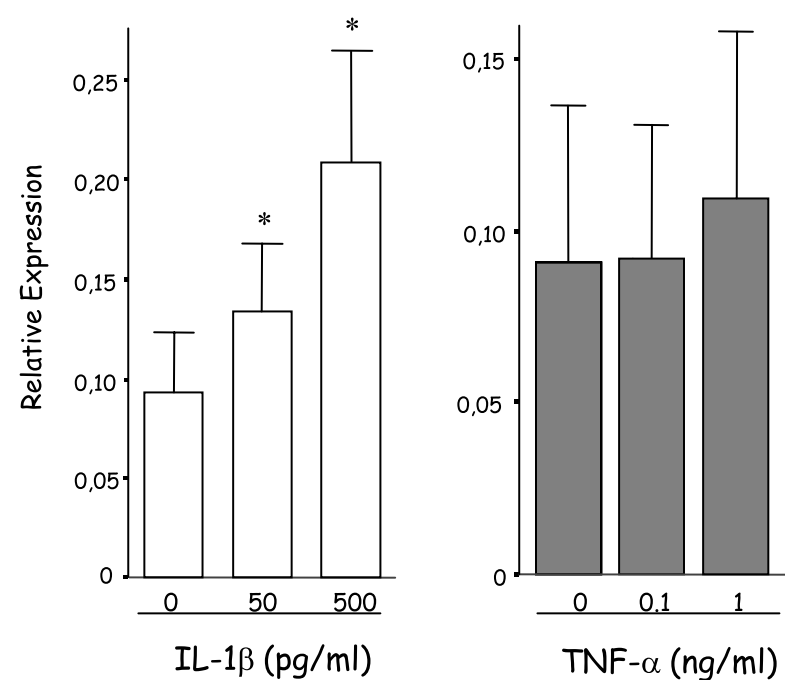

Figure 4 Effect of IL-1 $\beta$ and TNF- $\alpha$ treatment on $1 \alpha-O H a s e$ gene expression as evaluated by real-time RT-qPCR analysis. Messenger RNA levels were evaluated in endometrial stromal cells treated with and without different concentrations of the cytokines for $24 \mathrm{~h}$. Data from $n=6$ experiments were analyzed by real time $\mathrm{QPCR}$ and presented as mean \pm S.E.M. relative expression. ${ }^{*} P<0.05$ vs corresponding unstimulated controls.

\section{Expression of $1 \alpha-\mathrm{OHase}$ in eutopic and ectopic endometrium from patients with endometriosis}

Comparison of mRNA levels for $1 \alpha$-OHase in eutopic endometrial samples of patients with $(n=14$ and $n=13$ in the proliferative and secretory phases respectively) and without endometriosis by real time RT-qPCR demonstrated a significant increase for proliferative phase cultures derived from patients affected by the disease $(P<0 \cdot 05)$ (Fig. 6A). Western blot analysis confirmed that these differences were maintained at the protein level (Fig. 6B).

Three biopsies of endometriotic peritoneal lesions and nine biopsies of endometriotic cysts were tested for $1 \alpha$-OHase mRNA expression by qualitative RT-PGR. Amplified DNA products were consistently detected in all samples analyzed (Fig. 6C).

\section{Discussion}

Recent findings have emphasized the potential role of $1,25(\mathrm{OH})_{2} \mathrm{D}_{3}$ in decidual physiology (Zehnder et al. 2002b). To the best of our knowledge, this is the first study that has investigated the vitamin D system in human cycling endometrium. The presence of the enzyme that catalyzes the synthesis of the active form of vitamin $\mathrm{D}$ in cycling endometrium and its up-regulation in first trimester decidua, support the possibility that this hormone might be involved in some mechanisms of pregnancy establishment or maintenance.

Even more intriguing in this context is the observation that IL- $1 \beta$ caused a strong increase in $1 \alpha$-OHase mRNA expression in endometrial stromal cells. IL- $1 \beta$ is thought to actively participate in the synchronized cooperation between the endometrium and the preimplanting embryo under the influence of steroid hormones, both in mice and humans (Lindhard et al. 2002). In humans, secretion of embryonic IL-1 $\beta$ seems to be the first response of the blastocyst to the receptive endometrium, stimulating a second wave of cytokines essential for attachment of the blastocyst (Lindhard et al. 2002). We have herein demonstrated that $1 \alpha$-OHase is among those genes transcriptionally modulated by IL- $1 \beta$ at the endometrial level. Interestingly, in contrast to what has been observed for macrophages and endothelial cells (Pryke et al. 1990, Zehnder et al. 2002a), the mechanism of cytokine-induced $1 \alpha$-OHase activity at the endometrial level seems to rely mostly on IL-1 $\beta$. Indeed, from the results of this study, the TNF- $\alpha$-mediated effect on endometrial $1 \alpha$-OHase expression is not as potent as that obtained with very low concentrations of IL-1 $\beta$.

The effect of vitamin $\mathrm{D}$ in the uterus may be exerted either via the regulation of specific target genes (Du et al. 2005) or through the well established immunomodulatory effects of the hormone (Lemire et al. 1995). Among the target genes there are calbindins and the HoxA10 
A

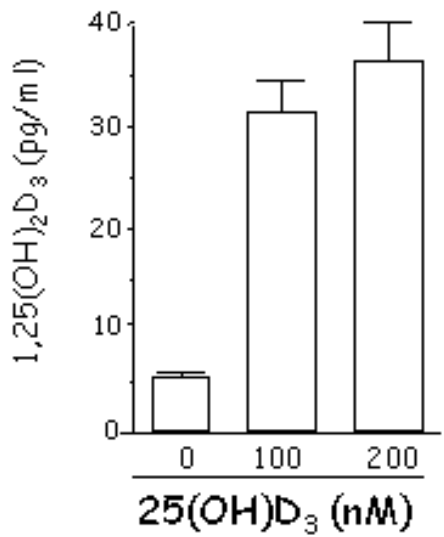

B
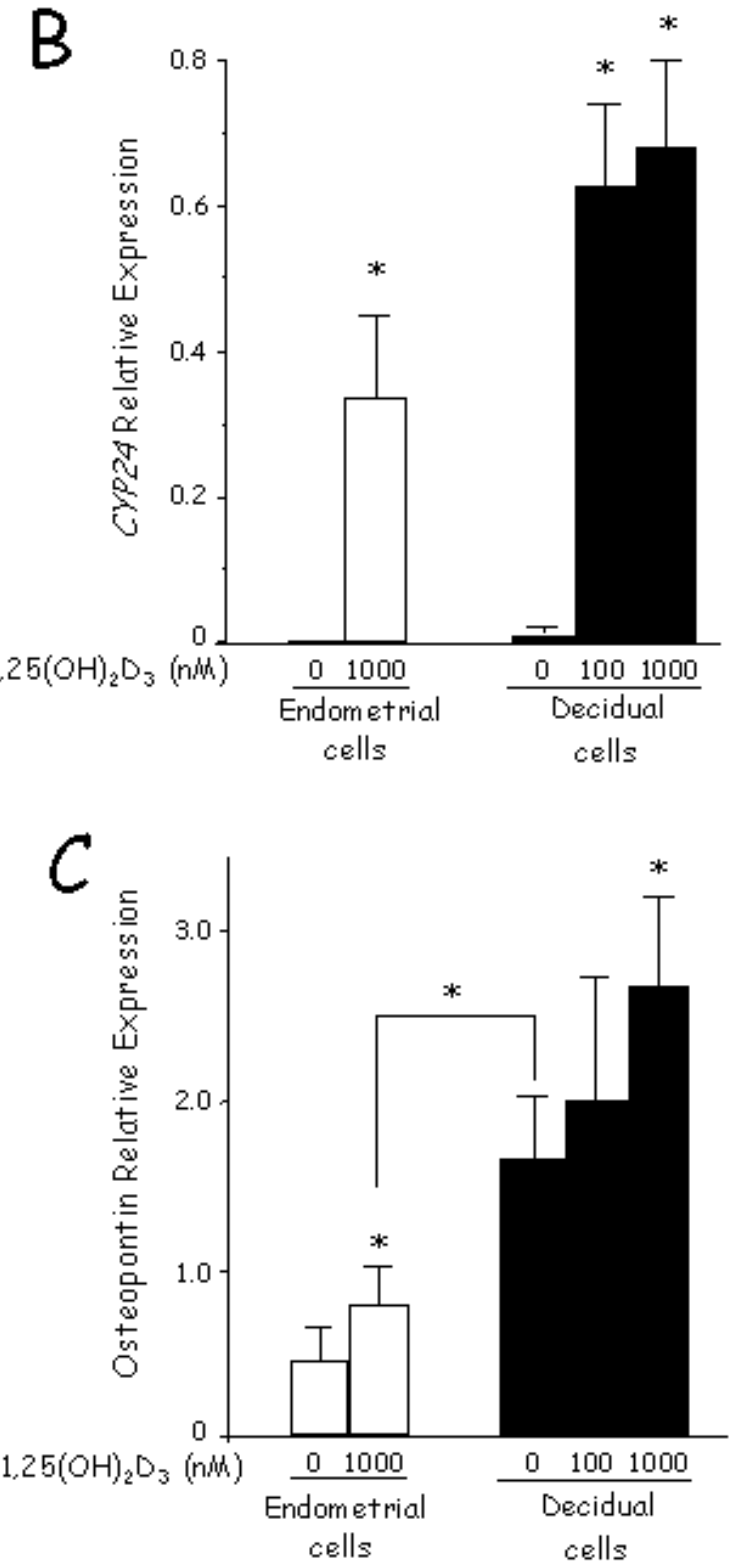

gene which are critical for implantation in mice and in humans respectively (Benson et al. 1996, Taylor et al. 1998, Nie et al. 2000, Salamonsen et al. 2002, Du et al. 2005) and are known to be transcriptionally regulated by vitamin D in different cell types (Rots et al. 1998, Nie et al. 2000, Du et al. 2005). We have herein identified osteopontin as another possible target gene regulated by vitamin $\mathrm{D}$. Osteopontin is an acidic member of the small integrin-binding ligand $\mathcal{N}$-linked glycoprotein family of extracellular matrix proteins/cytokines. This versatile protein is a major constituent of the uterine-placental microenvironment and exerts its influence as a component of the endometrial gland secretion and as a gene product expressed by uterine stroma contributing to a decidualization-like transformation that correlates with the degree of conceptus invasiveness Johnson et al. 2003). While $1,25(\mathrm{OH})_{2} \mathrm{D}_{3}$ has been shown to induce the gene in some tissues, this is the first demonstration of this effect in endometrial and decidual cells, giving further support for a role of the hormone as a local paracrine signal.

If we consider a possible action of $1,25(\mathrm{OH})_{2} \mathrm{D}_{3}$ as a natural regulator of the immune system, it is important to note that these effects can be viewed in the context of the local immune responses supposed to be critical for the development of a normal pregnancy. Indeed, in a successful pregnancy, the cytokine profile is thought to be shifted away from cell-mediated (T helper (Th)1-type) responses towards humoral immunity (Th2-type) (Hill et al. 1995, Viganò et al. 2002). Vitamin D promotes the shift away from Thl-type responses and favours a Th2-type immunity by inhibiting the secretion of IL-12, IL-2, TNF and $\gamma$-interferon by T cells, macrophages and dendritic cells (Limire et al. 1995, Muller \& Bendtzen 1996, D’Ambrosio et al. 1998, Long \& Santos 1999).

In the present study, we have also demonstrated expression of $1 \alpha$-OHase by ectopic endometriotic implants and the presence of higher levels in eutopic cells of women affected by the disease. As for many other molecules found to be aberrantly present in

Figure 5 Synthesis of $1,25(\mathrm{OH})_{2} \mathrm{D}_{3}$ in endometrial cells and transcriptional effects on specific target genes. (A) $1,25(\mathrm{OH})_{2} \mathrm{D}_{3}$ local synthesis from $25(\mathrm{OH}) \mathrm{D}_{3}$ was measured by an RIA assay. Endometrial stromal cells were cultured for $24 \mathrm{~h}$ in $1 \% \mathrm{FCS}$ culture medium in the presence or absence of $25(\mathrm{OH}) \mathrm{D}_{3}$. (B) Real time RT-qPCR analysis of Cyp24 mRNA in cultures derived from $n=3$ endometrial samples and $n=5$ decidual samples. Cells were treated with and without different concentrations of the hormone for $4 \mathrm{~h}$. Data are presented as mean \pm S.E.M. Cyp24 relative expression. ${ }^{*} P<0.05$ versus corresponding unstimulated samples. (C) Real time RT-qPCR analysis of osteopontin mRNA in cultures derived from $n=4$ endometrial samples and $n=4$ decidual samples. Cells were treated with and without different concentrations of the hormone for $4 \mathrm{~h}$. Data are presented as mean \pm S.E.M. osteopontin relative expression. ${ }^{*} P<0.05$ versus corresponding unstimulated or indicated samples. 
A

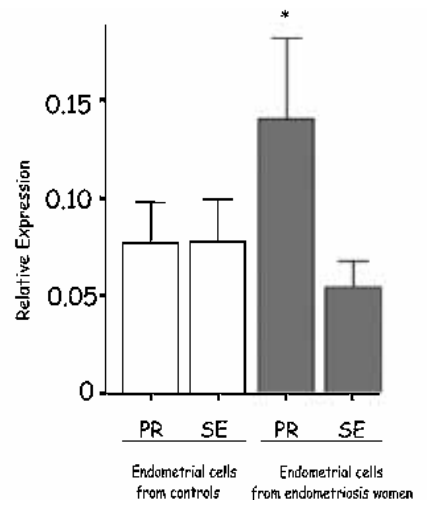

B

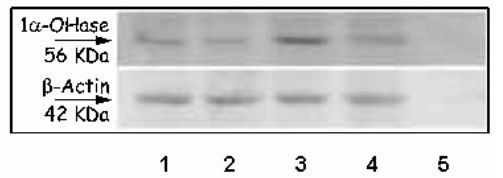

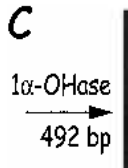

$\frac{C}{10-0 \text { Hase }} \frac{492 \text { bp }}{49}$

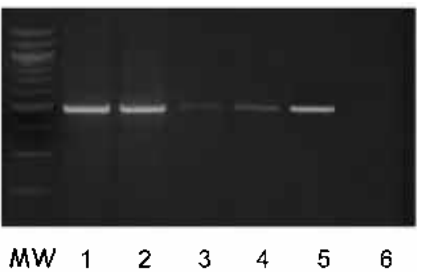

6

Figure 6 Expression of $1 \alpha-\mathrm{OH}$ ase in eutopic endometrial stromal cells from women with and without endometriosis and in ectopic tissues. (A) Real time RT-qPCR analysis of $1 \alpha$-OHase mRNA in cultured cells derived from $n=28$ eutopic endometrial samples from disease-free women and $n=27$ eutopic samples from affected women. Data are presented as mean \pm S.E.M. $1 \alpha-O H a s e$ relative expression. ${ }^{*} P<0.05$ versus corresponding secretory phase samples. PR, proliferative phase; SE, secretory phase. (B) Western blot profile of total homogenate of eutopic endometrial cells. Representative cases of proliferative (lane 1) and secretory (lane 2) phase eutopic endometrial cells from disease-free women and proliferative (lane 3) and secretory (lane 4) phase eutopic endometrial cells from affected women are shown. Lane 5 represents a negative control in which primary antibody was preabsorbed with a 100-fold excess of immunizing peptide. Detection of $\beta$-actin was used for protein load control. (C) Analysis of $1 \alpha$-OHase mRNA by qualitative RT-PCR in eutopic endometrial stromal cells of women with endometriosis (lanes 1-2, proliferative and secretory phases of the cycle respectively), in two biopsies of endometriotic peritoneal lesions (lanes 3-4) and in one biopsy of endometriotic cysts (lane 5). Lane 6 is the negative control prepared using all reagents and substituting $1 \mu$ l water for the reverse transcriptase. Size marker is shown on the left side of the gel (MW).

endometriosis, it is difficult to clarify whether the increased endometrial $1 \alpha$-OHase mRNA levels in the proliferative phase represent a primary event or a consequence of the disease. It might be hypothesized that a secondary endometrial response to the peritoneal inflammatory reactions, immediately following menstruation, is responsible for this increase. Alternatively, endometrium from women affected might be constitutively more able to produce vitamin $\mathrm{D}$. In both cases, the hormone, mostly for its ability to modulate cytokine production and inflammatory mediators (D'Ambrosio et al. 1998) may influence the functional activities of specific immune populations, such as natural killer cells that, in these women, are characterized by peculiar features (Vignali et al. 2002).

In conclusion, the results of this study support the following observations: (i) human cycling endometrium may be included among those sites capable of extrarenal synthesis and action of vitamin D; (ii) the enzyme $1 \alpha$-OHase is expressed in human endometrial stromal cells independently of the phase of the menstrual cycle but its expression is up-regulated in early pregnant versus cycling endometrium; (iii) IL-1 $\beta$ is a potent inducer of endometrial $1 \alpha$-OHase mRNA expression; (iv) endometrium also expresses the vitamin $\mathrm{D}$ receptor; (v) in endometrial and decidual cells, the Cyp24 gene, whose product catalyzes the first step of the degradation pathway of $1,25(\mathrm{OH})_{2} \mathrm{D}_{3}$, is strongly induced transcriptionally by the hormone; (vi) the osteopontin gene is a target of vitamin D action in both cycling and early pregnant endometrium; (vii) in endometriosis patients, the gene coding for $1 \alpha$-OHase is expressed also in ectopic endometrium and its expression is enhanced in eutopic endometrium during the proliferative phase.

Taken together, these results confirm the necessity to further investigate the functional role of the vitamin D system at the endometrial level.

\section{Acknowledgements}

The authors declare that there is no conflict of interest that would prejudice the impartiality of this scientific work.

\section{References}

Acker GM, Garabedian M, Guillozo H, Pecquinot MA \& Balsan S 1982 In vitro formation of 25-hydroxyvitamin $\mathrm{D}_{3}$ metabolites in endometrium: dependence on hormonal status of the rat. Endocrinology $1112103-2109$.

American Society for Reproductive Medicine 1997 Revised American Society for Reproductive Medicine classification of endometriosis: 1996. Fertility and Sterility 67 817-821.

Benson GV, Lim H, Paria BC, Satokata I, Dey SK \& Maas RL 1996 Mechanisms of reduced fertility in Hoxa-10 mutant mice: uterine homeosis and loss of maternal HOXA-10 expression. Development 122 2687-2696.

Christakos S, Dhawan P, Liu Y, Peng X \& Porta A 2003 New insights into the mechanisms of vitamin $\mathrm{D}$ action. Fournal of Cellular Biochemistry 88 695-705.

D’Ambrosio D, Cippitelli M, Cocciolo MG, Mazzeo D, Di Lucia P, Lang R, Sinigaglia F \& Panina-Bordignon P 1998 Inhibition of IL-12 production by 1,25-dihydroxyvitamin $\mathrm{D}_{3}$ : involvement of 
$\mathrm{NF}-\mathrm{\kappa B}$ downregulation repression of the $\mathrm{p} 40$ gene. Fournal of Clinical Investigation 101 252-262.

Delvin EE, Arabian A, Glorieux FH \& Mamer OA 1985 In vitro metabolism of 25-hydroxycholecalciferol by isolated cells from human decidua. Fournal of Clinical Endocrinology and Metabolism $60880-885$.

Du H, Daftary GS, Lalwani SI \& Taylor HS 2005 Direct regulation of HoxA10 by $1,25-(\mathrm{OH})_{2} \mathrm{D}_{3}$ in human myelomonocytic cells and human endometrial stromal cells. Molecular Endocrinology $192222-2233$.

Fritsche J, Mondal K, Ehrnsperger A, Andreesen R \& Kreutz M 2003 Regulation of 25-hydroxyvitamin $\mathrm{D}_{3}-1 \alpha$-hydroxylase and production of $1 \alpha, 25$-dihydroxyvitamin $\mathrm{D}_{3}$ by human dendritic cells. Immunobiology 102 3314-3316.

Hartwell D, Riis BJ \& Christiansen C 1990 Changes in vitamin D metabolism during natural and medical menopause. Fournal of Clinical Endocrinology and Metabolism 71 127-132.

Hewison M, Zehnder D, Bland R \& Stewart PM 2000 $1 \alpha$-hydroxylase and the action of vitamin D. Fournal of Molecular Endocrinology 25 141-148.

Hill JA, Polgar K \& Anderson DJ 1995 T-helper 1-type immunity to trophoblast in women with recurrent spontaneous abortion. Fournal of the American Medical Association 273 1933-1936.

Johnson GA, Burghardt RC, Bazer FW \& Spencer TE 2003 Osteopontin: roles in implantation and placentation. Biology of Reproduction 69 1458-1471.

Jones G, Strugnell SA \& De Luca HF 1998 Current understanding of the molecular actions of vitamin D. Physiological Review 78 1193-1231.

Kachkache M, Rebut-Bonneton C, Demignon J, Cynober E \& Garabedian M 1993 Uterine cells other than stromal decidual cells are required for 1,25-dihydroxyvitamin $\mathrm{D}_{3}$ production during early human pregnancy. FEBS Letters 333 83-88.

Kinuta K, Tanaka H, Moriwake T, Aya K, Kato S \& Seino Y 2000 Vitamin D is an important factor in estrogen biosynthesis of both female and male gonads. Endocrinology 141 1317-1324.

Kumar R 1980 The metabolism of 1,25-dihydroxyvitamin $\mathrm{D}_{3}$. Endocrine Reviews 1 258-267.

Lemire JM, Archer DC, Beck L \& Spiegelberg HL 1995 Immunosuppressive actions of 1,25-dihydroxyvitamin $\mathrm{D}_{3}$ : preferential inhibition of Thl functions. Fournal of Nutrition 125 1704s-1708s.

Lindhard A, Bentin-Ley U, Ravn V, Islin H, Hviid T, Rex S, Bangsboll S \& Sorensen S 2002 Biochemical evaluation of endometrial function at the time of implantation. Fertility and Sterility 78 221-233.

Long KZ \& Santos JI 1999 Vitamins and the regulation of the immune response. Pediatric Infectious Disease Fournal 18 283-290.

Muller K \& Bendtzen K 1996 1,25-Dihydroxyvitamin $\mathrm{D}_{3}$ as a natural regulator of human immune functions. Fournal of Investigative Dermatology Symposium Proceedings 1 68-71.

Nie GY, Li Y, Wang J, Minoura H, Findlay JK \& Salamonsen L 2000 Complex regulation of calcium-binding protein D9k (calbindin- $\mathrm{D}_{9 \mathrm{k}}$ ) in the mouse uterus during early pregnancy and at the site of embryo implantation. Biology of Reproduction 62 27-36.

Panda DK, Miao D, Tremblay ML, Sirois J, Farookhi R, Hendy GN \& Goltzman D 2001 Targeted ablation of the 25-hydroxyvitamin D $1 \alpha$-hydroxylase enzyme: evidence for skeletal, reproductive, and immune dysfunction. PNAS 98 7498-7503.

Peehl DM, Skowronski RJ, Leung GK, Wong ST, Stamey T \& Feldman D 1994 Antiproliferative effects of 1,25-dihydroxyvitamin $\mathrm{D}_{3}$ on primary cultures of human prostastic cells. Cancer Research 54 $805-810$.
Pryke AM, Duggan C, White CP, Posen S \& Mason RS 1990 Tumor necrosis factor-alpha induces vitamin D-1-hydroxylase activity in normal human alveolar macrophages. Fournal of Cellular Physiology 142 652-656.

Rots NY, Liu M, Anderson EC \& Freedmann LP 1998 A differential screen for ligand-regulated genes: identification of HoxA10 as a target of vitamin $\mathrm{D}_{3}$ induction in myeloid leukemic cells. Molecular and Cellular Biology 18 1911-1918.

Salamonsen LA, Nie GY \& Findlay JK 2002 Newly identified endometrial genes of importance for implantation. Fournal of Reproductive Immunology 53 215-225.

Salle BL, Delvin EE, Lapilonne A, Bishop NJ \& Glorieux F 2000 Perinatal metabolism of vitamin $\mathrm{D}^{1-3}$. American Fournal of Clinical Nutrition 71 1317S-1324S.

Tashiro K, Abe T, Oue N, Yasui W \& Ryoji M 2004 Characterization of vitamin D-mediated induction of the CYP 24 transcription. Molecular and Cellular Endocrinology 226 27-32.

Taylor HS, Arici A, Olive D \& Igrashi P 1998 HOXA 10 is expressed in response to sex steroids at the time of implantation in the human endometrium. Fournal of Clinical Investigation 101 1379-1384.

Viganò P, Di Blasio AM, Dell'Antonio G \& Vignali M 1993 Culture of endometrial cells: a new simple technique to completely separate epithelial glands. Acta Obstetrica et Gynecologica Scandinavica 7 87-92.

Viganò P, Gaffuri B, Somigliana E, Busacca Mi, Di Blasio AM \& Vignali M 1998 Expression of intercellular adhesion molecule (ICAM)-1 mRNA and protein is enhanced in endometriosis versus endometrial stromal cells in culture. Molecular Human Reproduction 4 1150-1156.

Viganò P, Somigliana E, Mangioni S, Vignali M, Vignali M \& Di Blasio AM 2002 Expression of interleukin-10 and its receptor is up-regulated in early pregnant versus cycling human endometrium. Fournal of Clinical Endocrinology and Metabolism $875730-5736$.

Vignali M, Infantino M, Matrone R, Chiodo I, Somigliana E, Busacca M \& Viganò P 2002 Endometriosis: novel etiopathogenetic concepts and clinical perspectives. Fertility and Sterility 78 665-678.

von Wolff M, Bohlmann MK, Fiedler C, Ursel S \& Strowitzki T 2004 Osteopontin is up-regulated in human decidual stromal cells. Fertility and Sterility 81 741-748.

Yoshizawa T, Handa Y, Uematsu Y, Takeda S, Sekine K, Yoshihara Y, Kawakami T, Arioka K, Sato H, Uchiyama Y et al. 1997 Mice lacking the vitamin D receptor exhibit impaired bone formation, uterine hypoplasia and growth retardation after weaning. Nature Genetics 16 391-396.

Zehnder D, Bland R, Williams MC, McNinch RW, Howie AJ, Stewart PM \& Hewison M 2001 Extrarenal expression of 25-hydroxyvitamin $\mathrm{D}_{3}$-1 $\alpha$-hydroxylase. Fournal of Clinical Endocrinology and Metabolism 86 888-894.

Zehnder D, Bland R, Chana RS, Wheeler DC, Howie AJ, Williams MC, Stewart PM \& Hewison M 2002a Synthesis of 1,25-dihydroxyvitamin $\mathrm{D}_{3}$ by human endothelial cells is regulated by inflammatory cytokines: a novel autocrine determinant of vascular cell adhesion. Fournal of the American Society of Nephrology 13 621-629.

Zehnder D, Evans KN, Kilby MD, Bulmer JN, Innes BA, Stewart PM \& Hewison M 2002b The ontogeny of 25-hydroxyvitamin $\mathrm{D}_{3}$ $1 \alpha$-hydroxylase expression in human placenta and decidua. American Fournal of Pathology 161 105-114.

\section{Received in final form 7 February 2006 Accepted 20 March 2006}

Made available online as an Accepted Preprint 22 March 2006 